\title{
O barroco enquanto aspecto do grotesco e do trágico
}

\section{The baroque as an aspect of the grotesque and the tragic}

Carmem Gadelha ${ }^{1}$ 


\section{Resumo}

Este texto examina aspectos da subjetividade moderna e da atual: seus modos de comparecimento na cena teatral, caracterizada pelas crises do drama, da representação, da narrativa. As indagações situam-se entre duas balizas: a obra de arte total wagneriana e as inquietações de Artaud. Corpo, espaço e tempo - tensionados entre os dois polos - apontam possíveis reconceitualizações do pós-dramático. Notamos fortes traços de lirismo coral e dissonante - eterno retorno de Dionísio. É necessário pensar as consequências disso sobre a noção de personagem: faltam contornos individualizados e profundidades psíquicas e históricas. Ressalta a alegoria, pensada a partir de Benjamin e Agamben.

Palavras-chave: Tragicidade; linguagem; filosofia; teatralidade; performatividade
This paper examines aspects of modern and current subjectivity: their ways of attending the theatrical scene, characterized by crises of drama, representation and narrative. The questions lie between two beacons: the total Wagnerian work of art and the restlessness of Artaud. Body, space and time - tensioned between the two poles - point to possible reconceptualizations of the postdramatic. We notice strong traces of choral and dissonant lyricism - eternal return of Dionysus. It is necessary to think about the consequences of this on the notion of character: individualized contours and psychic and historical depths are lacking. It highlights the allegory, thought from Benjamin and Agamben.

Keywords: The tragic; language; philosophy; theatricality; performativity

E-ISSN: 2358.6958

\footnotetext{
${ }^{1}$ Profa. Dra. Associada da Universidade Federal do Rio de Janeiro (UFRJ) - Atuando no Curso de Artes Cênicas - Habilitação Direção Teatral e no Programa de Pós-Graduação em Artes Cênicas (PPGAC). cafezeiro@uol.com.br
} 
Não me refiro à tragédia. Questiono tentativas de estendê-la ao niilismo cristão: aniquilamento e ascetismo apontados por Nietzsche (1982), desde A origem da tragédia. Acompanho as ressalvas de Benjamin (1984) quanto a aspectos trágicos do drama barroco. Tento compreender entrelaçamentos das heranças greco-latinas e hebraico-cristãs, observando tensões e alianças postas entre elas. Trato arkhé (origem) em múltiplos tempos e espaços, confrontados com a contemporaneidade: mundo e arte contrariam paradigmas modernos, balizados pelo Iluminismo e pela fundação das Ciências Humanas (Foucault, 1992).

Movo-me entre duas balizas principais: obra de arte total (Wagner); por outro lado, a desconstrução do espetáculo (texto e cena) por Artaud e as consequências sobre noções de corpo, espaço e tempo no teatro, tal como articuladas a partir dos anos 1960. Isto porque habitamos e transitamos, atualmente, entre extremos, problematizando a representação (Derrida, 1995; Deleuze, 1994, 1997; Deleuze \& Guattari, 1996, 2012) e vendo-a sempre de retorno. Isto viveu e sofreu Artaud (Gadelha, 2013), em combates ao que ele considerava clássico (incluam-se Wagner, primeiros encenadores, obras-primas).

Estudo a expressão de hoje, vendo-a próxima de um coro. Filosofia e teoria do teatro aliam-se, aqui, a comentários de espetáculos e performances, constituindo o campo especulativo. Transito entre os gregos, o século XVII, entre outros; e os dias atuais, num vai-e-vem de temas onde busco semelhanças e disparidades. Este passeio me obriga a atropelar cronologias para tentar alguns conceitos.

Walter Benjamin é um dos guias. Utilizo-me de seu "tratado" dedicado ao drama barroco alemão, para tentar um "ensaio": um método de abordagem sempre enviesado; um pensamento que se distribui em mosaico, justapondo e confrontando elementos heterogêneos. Estas vacilações têm contornos borrados e fronteiras indefinidas; podem-se dizer grotescas. Se ambicionam a verdade, só a alcançam de forma parcial e precária, mantendo-se sua abertura para a beleza e a dúvida. Aí encontramos Brecht, um artista produtor de imagens; um investigador que se move entre lacunas; um filósofo tenaz.

\section{Novo coro, nova festa}

Inicio, agora, considerações sobre o coro. A "festa" de Artaud $(1985,1987)$ é disruptiva. Pressiona, até o limite, a narrativa teatral, a partir de seu outro: não-teatro que preenche o teatro, circunda-o, fratura-o e mostra vazios plenos de teatralidade. Nos processos, articulações e entrelaçamentos com a subjetividade. Tais potências trágicas transbordam da moldura teatral wagneriana: um espaço cúbico, praticado e percorrido no sentido da profundidade; um corpo de ator capaz de reunir e sustentar voz (artes do tempo) e movimento (artes do espaço e das visualidades). O transbordamento artaudiano desfaz os elos da narrativa e conduz a um "fora" que retorna e cria dobras (Deleuze, 1995), inclusive políticas. Nessas dobras, os vazios são potências de engendramentos e incompletudes postos entre territórios instáveis. Daí aos contornos (ou falta deles) do espetáculo atual. Isto atinge o personagem, visto na sua tarefa de dar suporte à narrativa, percorrendo o tempo e o espaço que a constituem. 
Quebradas essas cadeias, restam máscaras traçadas em linhas tênues ou borradas, entre as quais se insinua um análogo das turbas dionisíacas anteriores à polis e à tragédia (Detienne, 1988). Nietzsche (1982) vê, na tensão Apolo/Dionísio, a individuação/desindividuação que ainda não distingue trágico e cômico. A instauração do diálogo (logos partido) faz indagar sobre o que separa e une singular e múltiplo.

Lembremos que coro e cena euripidianos vislumbram um mundo de harmonia, livre de turbulências. Dão voz ao homem teórico (força crítica e desanimadora), em oposição ao homem trágico, afirmativo e criador (Nietzsche, 1982). O ascetismo teórico permitiu moldar uma "moral de sacerdote" correlata à ressentida "moral de escravos": apego ao passado que impede viver o presente e vislumbrar futuros (Nietzsche, 2000). A inépcia para a dor extirpa a alegria e garante uma modernidade voltada para o cálculo, o conhecimento binarizado - cabeça separada do corpo, rosto dividido em significância/subjetivação (Deleuze \& Guattari, 1996) e sujeitado à dívida com Deus, inscrita no Livro (Deleuze, 1997). Ética e estética de catecismo dominam o Ocidente - exibe-se uma falsa tragédia convertida em melodrama; o corpo esquece-se das dores da (in)diferenciação e se torna histrionismo mimético (Nietzsche, 1999). Nietzsche se refere, quanto a isto, ao que costumamos chamar de "tradição aristotélica", a partir do Renascimento. Lembremos que o palco à italiana, de rígidas proporções perspécticas, tem ambições de objetividade que tentam controlar o mundo produzindo imagens de perfeição e harmonia para apoiar o Estado soberano (Szaniecki, 2007) e definir moral e estética burguesas. A visão perspéctica, coordenada por distribuições geométricas dos objetos no espaço, pressupõe uma ordem de representação a ser assimilada por um sujeito universal. Compreendidos como materializações da ordem do mundo, sujeito e objeto exibem-se para dar visão de si: o palco é tecnologia de poder e narrativa. Mas, Nietzsche (2000) argumenta: em Kant, o entendimento sabe que seus objetos são ininteligíveis.

De fato, com Deleuze e Guattari (1996), um "excesso de sentido" transborda da paisagem e dos rostos. Entre poderes e devires, desfazem-se, hoje, dicotomias e hierarquias do tipo pai-filho. Em dobra, os extremos pressionam um ao outro, encontrando, na linguagem, porções arcaicas. Refeito, o coro é novamente de bacantes: des-identidade libertadora da tragicidade, turbilhonando a ação clássica, que tem suporte em duas retas coincidentes: princípio, meio, fim (tempo cronológico) e causalidade. Desfeitos os elos, afirmam-se sentidos opostos; o presente é indistinção de passado e futuro (Aion). A "ação" tornou-se agir: verbo no infinitivo, cujos paradoxos são potências de acontecimentos multidirecionais. São forças que operam em Diferença em relação ao "bom senso" (seta a indicar a "boa" direção) e "senso comum", que identifica o diferente sobre o pano de fundo do Mesmo (Deleuze, 1974).

O corpo adota regime grotesco, proliferando simulacros: não há medida ou relação com cópia ou ideia (Deleuze, 1974). A personagem perde profundidade histórica e psicológica, assumindo espessura de simples figura (máscara, alegoria). Sem unidade de sentido, o espetáculo abriga trocas de posição atores-público. Ainda que a cena aconteça sobre o palco italiano "arborescente" (cruzamento de sincronia por diacronia; tronco dos paradigmas provedor de sentido para os ramos sintagmáticos), a reterritorialização não retorna ao aristotelismo, porque se mantêm potências múl- 
tiplas de rostidade e paisageidade, a forcejar por usos que escapem às determinações da sala.

Com Zé Celso, não há rostos, mas apenas quase-máscaras: corpos multidimensionais, transmutando-se uns em outros. As páginas de Os sertões (Euclides da Cunha) são arrebatadas das unidades históricas. O rosto é uma política; desfazê-lo também é; as desterritorializações arrastam a arte para o a-significante e o a-subjetivo (Deleuze, 1996). No longo espetáculo de 26 horas, Os sertões é (são) novamente trágico(s). Este trânsito se serve da tragédia para fugir dela em todas as direções: tragicidade fundada em rizomas.

Do ponto de vista político, o coro, análogo à multidão contemporânea (Hardt \& Negri, 2005), dá sustentação teórica para pensar a subjetividade fora de determinações universais. Isto exige redimensionar o conceito de personagem dramática. Observo a expressão lírica a partir de um "eu" que vive a separação/união com o uno primordial, tal como mostra Nietzsche (1982) a respeito de Arquíloco. Eu/Nós em doloroso processo de distinção/indistinção. Temos, com Michel Melamed e Denise Stoklos, máscaras que fazem, desfazem e refazem esses espaços em dialogismo (Bakhtin, 1997).

\section{A máscara, a mônada, a alegoria barroca}

As máscaras requerem, agora, incursões pelo pensamento de Walter Benjamin (1984). Em O drama barroco alemão, o espaço-tempo da "mônada" se define por uma forma no presente: tensão entre passado e futuro, pré e pós-história de uma ideia. Contém a totalidade, sendo parte de um mosaico: cena multiplicada infinitamente, em diferentes planos de narrativa. Ela, a cena, é fragmento intemporal da história, fora de causalidade e cronologia, numa representação dos confins da vida, da civilização, da razão. O louco e o selvagem são personagens recorrentes. Aqui encontramos uma estrutura espetacular não-aristotélica e herdada da Idade Média, embora estudiosos renascentistas tenham tentado assimilar o barroco ao aristotelismo.

No espaço-tempo monádico, transita a "alegoria", que se refere a allós, o outro; agourein é um falar da ágora, linguagem pública. Fala do outro, outro da fala, outro da cidade, fala do si-mesmo como um outro perfazem a reunião e o trânsito entre diferentes figuras: metáfora (tensão entre um sentido literal e um figurado); metonímia (relação qualitativa entre referentes: ouro para dinheiro, autor para obra - "um Picasso"); sinédoque (a parte pelo todo). As personagens encarnam abstrações; a alegoria diz uma coisa e significa, incansavelmente, outra; o "um" e o "múltiplo", o "mesmo" e os "outros" proliferam. Aí se encontra a relação entre o destino e a morte (seu significado, enganos, fantasmas, ritualizações, inexorabilidade). Uma bela moça revela ser um esqueleto. As figuras são reversíveis: a sala de trono pode ser um cárcere, a alcova uma sepultura.

A alegoria não é, para Benjamin (1984), escatologia. Ela vai da situação presente ao retorno da Origem. Este retorno não é também nietzschiano: pode melhor caracterizar-se como desejo de regressão a um paraíso perdido. Deste modo, ele tem parentesco com o Pecado Original e a busca, sempre frustrada, de Salvação. A alego- 
ria é proteiforme: o princípio demoníaco (Proteu) do Múltiplo, da ilusão, do escárnio produz uma festa de cores que esconde a catástrofe ou a anuncia. Não se trata de narrar biografias e trajetórias individuais, mas de apontar um destino paradigmático.

Todas as alegorias remetem à morte; provêm dela. A ruína é um fragmento morto, resto de vida que reluz na transitoriedade das significações. Os fragmentos esquartejam o sentido da linguagem e do mundo, cujo fundo vazio prolifera signos. As ruínas cintilam e transmutam-se em abundância. A morte mediatiza os planos; ela é moeda de negociação entre o vazio e o preenchimento alegórico. A relação com a morte é dupla utopia: do absolutismo da significação e transmutação de todos os signos, mas caindo sempre no vazio, porque nos dois casos o significado é obliterado. O alegorista quer alcançar a fixação da linguagem na inalterabilidade do texto (a civilização é do Livro e do livro), mas jogando, desconfiadamente, com seu permanente movimento; pretende salvar-se da história e do destino, dar eternidade ao que é passageiro e fugacidade ao funesto. A violência alegórica é tanto aniquilamento quanto festa do significado. Quixote (o louco) e Pinóquio (o poético fantasista) comportam-se como senhores da significação. Conforme aponta Foucault (1992) em As palavras e as coisas, o louco e o poeta constituem duas experiências culturais básicas no Ocidente, a partir do advento da modernidade e a ruptura promovida por ela entre a linguagem e as coisas. O louco é aquele personagem que, frequentador do barroco (caso de Quixote) e da psiquiatria do século XIX, habita o homossemantismo, jogando sem regras com as noções do Mesmo e do Outro. Ele é Diferente por não conhecer a Diferença. O poeta reconhece as diferenças, mas arbitra a semelhança ou a descobre sob o fundo mesmo da diferença. Neste arbítrio, vivem as mentiras e fabulações que sustentam o nariz alegórico de Pinóquio. Face a face um com o outro, louco e poeta trafegam nos limites do marginal, do arcaico e imemorial, das identidades e diferenças, promovendo o acolhimento de contrários.

$\mathrm{Na}$ tradição hebraico-cristã, o desejo de tudo saber (e tudo figurar) é demoníaco. O projeto de salvação mergulha no engano da multiplicação de formas. Lembremos que, na vertente greco-latina do Ocidente, podemos pensar em Dionísio e sua máscara: ela é alegoria do trânsito entre o Um e o Múltiplo - movimento trágico de tensão com a forma e a unidade apolíneas: eterna desmedida do que se volta para a indeterminação e o inacabamento. A alegoria é sempre de outra(s) alegoria(s). Representação de representação, ao infinito.

As representações remetem, com Agamben (2007), à capacidade de jogar e amar; viver no interior de uma estranheza, entre o dizível e o indizível. Eis a subjetividade, na contingência de um poder-ser e um poder-não-ser. Este espaço é um vazio de sujeito. A mônada e a alegoria habitam essa potência de subjetivação, em tensões e contrastes de que fala Benjamin (1984); potência de grandeza e miséria, a acumular ruínas que se insurgem contra o aniquilamento. Hoje, o agir se faz entre a potência e o ato, como verbo no infinitivo, entre o possível e o real, o criar e a efetuação da obra. Movem-se forças políticas onde pulsa o poder constituinte no âmbito do poder constituído, para abalá-lo. As máscaras operam em excesso e falta, borrando as fronteiras do si-mesmo e do outro. Novamente nos defrontamos com o desmanche da cena clássica e wagneriana por Artaud. Basta pensar em dissoluções de gênero: en- 
cenações de romances sem adaptação (Farias, 2019), como o romance-em-cena de Aderbal Freire-Filho (A mulher carioca aos 22 anos e $O$ púcaro búlgaro, de Campos de Carvalho). Trata-se, aqui, de verdadeira dessacralização: o romance invade uma cena que, para acolhê-lo, inventa uma teatralidade não apegada à literatura dramática. Ela está nas figuras que transitam falando em terceira pessoa e agindo em primeira; ou nas trocas de nomes do que se supõe ser um só personagem, constelado. Ou se trata de um feixe suportado por um só corpo.

Profanar é devolver ao uso comum o que foi sacralizado; libertação do sagrado, estabelecendo novos usos, em impensadas possibilidades. Agamben (2007) acompanha Benjamin: sendo o capitalismo a nova religião que tudo abarca, é necessário "profanar o improfanável". Destituir o Eu cartesiano (soberano e sagrado). A máscara grotesca se encarrega de acionar potências do impessoal, o pré e pós-individual que habita o pré e pós-dramático - tensão que trafega entre Wagner e Artaud. Aderindo ao comum, a máscara não pertence nem ao Eu nem ao Outro. Assim o teatro luta para escapar ao "absoluto improfanável" do capitalismo, que submete a experiência à "sociedade do espetáculo" (Dèbord, 1997). Corpo e espaço são forças que atuam em tenso diálogo com as imagens que os alienaram - já mostrava Benjamin (1992). Não é demais lembrar o que depois Deleuze (1992) chamou "sociedade de controle"; ou as máquinas "24/7" e os sujeitos insones (Crary, 2014).

\section{Dispositivos e disposições contrárias}

Profanar, aqui, é lutar no interior dos dispositivos de poder, inclusive aqueles manifestados na autoridade do texto teatral, restituindo aquilo de que se viu privado o teatro: a fala e o corpo, dominados pela separação de si, via representação e cena "de Estado" (Shaniecki, 2007) sobre o palco à italiana. Novamente nos encontramos com Artaud X Wagner. Penso com Derrida (1995): as investidas de Artaud vislumbram a recuperação de uma tragicidade situada entre a morte e o nascimento do teatro na polis grega: um intervalo anterior e posterior ao êxtase e ao espetáculo - um tempo, permito-me a analogia, aiônico ou monádico. São essas postulações que permitem propor o desmanche da cena wagneriana: ela se desfaz e refaz, na luta com Artaud, em reconjugações de uma com a outra, situadas pré e pós-dramaticamente. Daí o aparecimento da máscara alegórica, grotesca e monstruosa no seu hibridismo e na instalação de uma temporalidade que desdenha cronologias, apostando num passado parodiado - jogo de destituição de poderes e de história curto-circuitada. A alegoria não é otimista ou pessimista, mas afirmativa e produtora de mundos.

Afirmação que remete ao génos, onde está implicada a origem, desde que não vista como única ou unificante. Isto seria tomar o génos com um prefixo negativo (in/ genuidade - perda de referência de si e do outro); mas quero tomá-lo positivamente: in(em)génos, no interior do princípio gerador e perpetuador da vida e da potência em sua multiplicidade. No génos, dá-se o lugar de cada um naquilo que o ultrapassa: o antepassado e o descendente, inscrição cósmica imemorial e sempre presente. Aí abole-se o tempo cronológico: o teatro surge como a celebração do mais irrestrito apelo a um nome, a um pronome $(\mathrm{Eu})$ e a um impessoal trazido pelas máscaras de 
Apolo e Dionísio.

Artaud (ator, poeta, encenador, autor) jamais será apenas Eu, na sua atividade seminal e iconoclasta de artista sem obra. A pré ou pós-individualidade recusa o dilema consciência/inconsciência, não faz aparecerem neuroses; desmancha qualquer pretensão a um Eu robusto que impeça a passagem dos devires (Deleuze, 1997): alegria, dor, co-moção - Eu e Outro, numa diferença consigo, pertença e não-pertença a si. A cena alegórica contemporânea permite novamente pensar a linguagem do teatro como uma luta com e contra o palco, qualquer que seja ele, inclusive a falta dele. Produção, adesão, resistência aos dispositivos, na acepção de Agamben (2012): aí se dão subjetivações para além das determinações do cubo euclidiano consagrado por Wagner. Appia cedo mostrou forças arquimedianas (corpo/espaço/tempo) que distinguem cena e palco.

Os dispositivos atuam para deflagrar ou bloquear forças, tentando direcioná-las, num jogo de poderes e saberes que os condicionam e são condicionados por eles. No "corpo a corpo com os dispositivos" (Agamben, 2012, p. 44), podem romper-se usos e destinações, devolvendo "a um possível uso comum" (idem, ibidem), aquilo que foi capturado pelos poderes. Daí a profanação do que estava indisponível e sacralizado. Um "contradispositivo" é acionado para restituir aquilo que um ato sacrificial havia separado. É o caso das performances de sangue e risco de morte; um ato sacrificial que se assenta num paradoxo: sobre o suporte da carne dilacerada, retorna o corpo abstraído e alienado pelo trabalho e as imagens, mesmo que em sua doação ao perigo da morte e ao acaso. Marina Abramovic, em Rhythm 5, espalha pedaços de madeira e os embebe em gasolina sobre uma estrela posta no chão. Toca fogo na estrela e se deita em seu interior. $O$ fogo cresce até que alguém se levante e retire de lá o corpo da performer. Em Suz 1O/ Suz (La Fura dels Baus, 1985), pedaços de carne crua postos num balde são mastigados; o sangue que resta é bebido e atirado entre os atores, um no outro - conforme descrições de ambos os exemplos, feitas por Alessandra Lima de Carvalho (2018). É então que as alegorias refazem vínculos com o arcaico e o arquetípico. Temos hoje ritos teatrais e performativos que não ambicionam narrar, mas podem remeter a fragmentos de histórias já contadas. Faz parte desses ritos induzir-nos a procurar os elos e reconhecer as referências das narrativas do passado, incluindo a história do teatro e da arte: presente que contém e refaz temporalidades e representações. Os dispositivos visam a ser máquinas produtoras de subjetivações; estas também operam no sentido do desmantelamento daqueles. Algo semelhante se dá com a nova cena, que repudia dispositivos para compor-se com eles em novas configurações, subjetivações e narratividades, abrigando atores e performers.

Em Amazona (Teatro de Caminho, direção de Ricardo Cabral, Rio de Janeiro, 2018), o dispositivo (alegórico) é a cidade - seus espaços colonizados e colonizadores, seus trajetos obrigatórios. Em correria através dela, atores e espectadores são todos guerreiros em luta para fazer ressurgir a floresta que deu lugar - entre vales, rios e mares - ao asfalto e ao concreto que empurraram para baixo e para os lados as cenas da origem. A heroína é coletiva: amazonas são mulheres míticas, descendentes de Ares (deus da guerra) com a ninfa Harmonia. É preciso regar o chão da frente da Igreja da Candelária, semear o asfalto para que brotem o retorno e a vingança da 
floresta. É preciso atravessar ruas e desbloquear calçadas, depositar sementes entre as frestas das pedras portuguesas; buscar o que é vivo e reverbera, ocupando espaço e revertendo as ruínas em novas construções. Os percursos exigem paradas, evocações, diálogos, numa caça à resposta sobre por que não abandonar a cidade. Amazona começou a nascer pouco depois da morte de Marielle Franco: pleno luto, como requer o barroco. O elenco arriscou ensaiar e performar nos espaços públicos; um saiu pelas ruas com vara e iscas (celular, sandálias, nota de cinco reais), pescando pessoas; outra veste maiô vermelho de super-heroína de patins e capa turquesa com a inscrição "posso ajudar"; uma terceira deu aulas de como subir em árvores. As mônadas são nômades: máquina de guerra em combate com o sedentarismo de Estado, conforme se vê desenvolvido, a partir de Deleuze (Gadelha, 2018). O combate não é contra, mas entre forças que fazem reviver Pentesileia, a rainha que lutou ao lado de Príamo para salvar Troia e foi morta por Aquiles, que não pode deixar de apaixonar-se por seu belo corpo morto. Pentesileia é Marielle, o Rio de Janeiro - alegorias de nascimento e morte.

\section{O herói e os simulacros}

Volto às mônadas. É em sua descontinuidade que se vislumbram vizinhanças entre as disparidades e arriscam-se entrechoques de extremos. Daí a captura de cintilações de origens; eterno retorno que se dá ora na figura do Mesmo (a repetição, a cópia das ideias, a cena clássica), ora na Diferença - os simulacros (Deleuze, 1974). Nesta festa das formas e das nomeações, posso entrever a máscara de Dionísio ao lado da de Artaud, saudando o anúncio de tempos curto-circuitados. Neles comparece a bela passagem de Benjamin (1984) onde se distinguem pontos de inflexão entre a cena grega e o que se convencionou chamar de "tradição aristotélica", numa crítica à atitude dos comentadores de considerar elementos da tragédia (a fábula, o herói, a morte) próprios também do drama barroco, como se houvesse entre ambos uma origem e uma essência comuns. Mais do que isso, continuidade de um no outro.

Porém, Nietzsche verificou a perda de consistência trágica à medida que avança o domínio do pensamento platônico-aristotélico: niilismo da razão que alcança Bayreuth. Já não sabíamos ser gregos desde os gregos. Com Eurípides, não é demais insistir, já não entendemos a especificidade do conflito do herói com o meio: ele se põe entre a consistência inaugural e anunciadora de um povo que ainda não existe, mas estará sempre por vir (Deleuze, 1997); e a dívida para com os deuses e o génos, que tanto impelem ao agir e ao erro quanto exigem reparação. Passado e futuro pressionam o presente - tempo aiônico do "pré" e do "pós". O destino é inexorável, aprendemos com Ésquilo, mesmo que a morte não venha a se consumar ao fim da jornada da tragédia (caso da trilogia Oréstia). A ameaça de catástrofe permanece, ainda que as forças cósmicas se encontrem provisoriamente apaziguadas; qualquer movimento de uma delas pode trazer desestabilização e caos. O herói é silencioso, embora sua fala seja abundante. Na sua solidão, ele não pode dizer um Eu que demarque individualidade. Toda linguagem é insuficiente, impotente, no trânsito entre o dizível e o indizível. O Eu pronunciado contém o Nós - lírica coral manifesta e, ao 
mesmo tempo, implícita na máscara individual: o herói se remete tanto ao génos quanto ao coro e ao espectador, incluindo também seus antagonistas. A mudez e a incomunicabilidade dão-se tanto por falta de palavras, quanto por excesso: eloquência e impotência coincidem. A morte está sempre à espreita, porque o Eu é uma impossibilidade. O herói é a própria cidade e um "outro" dela mesma, que the doa a sua voz tanto quanto silencia, porque agencia um não-saber. A morte sacrifica, mas confere vitória sobre a falta de vigor das antigas leis. Tal ambiguidade é também da proliferação do sentido da fala oracular: múltiplo outro da cidade e do herói - silêncio pletórico, enigma e revelação. O rei arcaico era modelar; sua autoridade provinha de uma ordem cósmica de cujas forças ele participava desde tempos imemoriais. Ele era o herdeiro do seu génos, explicitando em si mesmo tudo que se encontrava desde sempre marcado no destino dos seus. Ao lado do basileu se sentava o poeta, encarregado de manter, com os ritos, esta narrativa e a narrativa do mundo dos deuses, articulando-as para atualizar a verdade cósmica. Posteriormente, estará em jogo, no herói, uma excelência não adaptável ao mundo da polis. Ou melhor, o herói aponta a falência da ética ditada pelo mito. Há nisto, mais uma vez, ambiguidade. Antígona não pode deixar de atender aos imperativos religiosos da tradição dos ritos fúnebres: dever para com os mortos, violado pela cidade. Ao mesmo tempo, a cidade requerida pela ação ainda não existe e não pode responder aos apelos por mudança.

Do mesmo modo, a máscara contemporânea repete o sacrifício do corpo na mudez de uma fala que não comunica; ela representa o irrepresentável. Trágico é o vazio, a distância entre a palavra, a ação, a situação - mesmo que a tentativa seja fazer presente a presença, deflagrando o perigo de morte. Ela será a testemunha paradoxal da impossibilidade de uma pura e absoluta presença, conforme a queria e pela qual se atormentava Artaud. A performance é da própria morte alegórica. Isto apontam o sangue e o delírio de uma carne exposta e, supõe-se, sem mediações com o corpo sede de toda experiência transmutada em linguagem. Não há aí passado e futuro, já que se encontram solapadas (e sacralizadas) as narrativas. Quanto mais acuado pelo destino indeterminado, mais distante se torna o Eu, entregue ao devir. Eis o eterno retorno de Édipo, carregado de silêncio eloquente. Ele propicia novamente à cidade contemporânea furtar-se ao vazio de sentido e significação, devolver-se a si mesma.

Arrisco-me a dizer que a vocação barroca para as misturas e as dissoluções de contornos promove o encontro da festa ancestral dionisíaca com o desfile e a procissão. Isto se insere numa linguagem carnavalesca, embora às vezes funesta, do mesmo modo que a cena contemporânea, pondo à prova os limites da resistência do corpo para dar, com isso, testemunho de sua presença. São sinais do enfrentamento do acaso - outra versão e outro nome para destino. Fustigar o acaso pode ser recurso de fuga ao permanente desejo de controlá-lo, na sociedade superinformada e tecno-científica. Pode-se supor que estaria aí o trágico, na nudez do acaso, seu último reduto numa sociedade saturada por imagens; sociedade tagarela, porém não loquaz.

O drama barroco não tem heróis, mas apenas traços gerais de configurações subjetivas. As figuras se remetem às alegorias do luto. Isto pode valer também para as "personagens" contemporâneas, à diferença de que estas já não dispõem nem mesmo da ação. O que as move é o acontecimento, conforme pensado por Deleuze 
(1974). Estas figuras se dão como simulacros - consistência de máscaras sem passado e futuro, sempre em iminência de perda do nome e de sua proliferação (Lógica do sentido). Temos hoje rituais onde o limite da representação pressiona o limite da vida, pensada para além do fato biológico.

\section{Sócrates e o príncipe barroco}

A dignidade do príncipe barroco, por sua vez, é modelar para a construção do absolutismo e do Estado Moderno: o projeto histórico está em curso na teleologia de poder secular que subjaz às tramas. Mas o drama barroco instala-se também na resignação cristã (renúncia à vontade, abandono do mundo). Em suas altas aspirações, o príncipe equipara-se ao santo no drama de martírio. A renúncia cristã pronuncia-se nos mistérios e moralidades medievais. Daí toda analogia com a tragédia ser forçada e possibilitada apenas pela ideia geral de drama. Arrisco-me a dizer que essa analogia tem suporte na forma da alegoria. Benjamin (1984) aponta a inflexão que a morte de Sócrates impõe ao espírito grego. Esta inauguração do drama de martírio soa como paródia à tragédia; uma paródia ascética, na qual o trágico se esvai em favor da razão. Com Platão, a medida necessária é expulsar o poeta, agora inútil e pernicioso, com seu demonismo proliferador de simulacros. Ao novo ciclo pertence Eurípides e pertencerá o estoico Sêneca. A morte de Sócrates dá lugar ao diálogo platônico, substituindo o elemento agônico pela disputa filosófica. No lugar do herói, surge o mártir em expectativa de imortalidade. Com Sócrates, a palavra enigmática do herói transforma-se em preleção a discípulos. A ironia socrática em tudo se opõe à ironia trágica, uma armadilha inconsciente da fala. Sócrates é um pedagogo; sua morte é, para Benjamin, histriônica.

O drama barroco assenta-se sobre sortilégios e não sobre a tragicidade do oráculo. Não há hybris onde imperam a consciência e o Livre Arbítrio. A figura de Sócrates dá a ver as diferenças do drama barroco de martírio em relação à tragédia anterior ao influxo decadente e racionalista. Ao mesmo tempo, esta anterioridade insinua afinidades com a cena popular da Idade Média, tão sagrada quanto profana, que dá origem ao barroco: o carnaval remete às saturnais e às festas dionisíacas. Sócrates é confluência de uma temporalidade pré e pós-tragédia. Ou, com Artaud, pré e pós-morte de Dionísio na polis - a véspera, o amanhã, o limite (Derrida, 1995). Por outro lado, mais um elo se junta a Sócrates no drama de martírio: a figura de Cristo e a reevangelização nas ruas da cidade medieval. A rarefação da tragédia dá ensejo à tentativa de sua assimilação ao drama barroco, cuja perspectiva individualizante sustenta o sentimento de luto (trauerspiel = espetáculo do luto). A mobilidade da cena herdada dos medievais, que ocupavam o espaço da cidade com a exemplaridade da narrativa bíblica e hagiográfica, faz do corpo de Cristo um viajante do tempo: a pedagogia do corpo dilacera a carne para promover a salvação.

Os dramaturgos barrocos alemães, segundo Benjamin (1984), têm relação estreita com o luteranismo - melancólica distância da vida cotidiana e mundana. A graça admissível aos luteranos, que não creem em milagres, é unicamente a própria fé. A demonstração das virtudes burguesas de obediência ao dever modela a melan- 
colia, ela mesma uma alegoria da recusa à vida terrena como expressão de alegria: o ascetismo torna-se assepsia, ao contrário dos espanhóis ligados à Contra-Reforma, impregnada de vida profana. Daí a permeabilidade a formas carnavalescas de expressão, cujo exemplo maior é Calderón. Considere-se, em meio a tudo isso, o movimento laicizante do barroco. Há um vácuo entre o céu e a terra, preenchido e problematizado (prismatizado) pela alegoria. Enquanto esta é pletórica e prolixa, o símbolo é totalizante e lacônico; aponta o futuro e o fatídico; ele é breve, solene e religioso. A ordem simbólica é antitrágica porque recusa o desmedido, combinando a forma e o ser que ela figura - perfeição alcançada pela escultura grega.

A alegoria é um conceito em forma sensível; desdobra-se sempre em outras, no tempo e no espaço, enquanto o desejo do símbolo é fixar-se e fixar significações. A alegoria representa e narra, confronta tempos, espaços, pontos de vista. Arrisca-se a certa dispersão indesejável ao projeto clássico. O símbolo é cópia de ideias, apela para um presente eterno; a alegoria é proliferação que opera no âmbito do simulacro, cavando abismos nas significações que ela finge abraçar. A alegoria é violenta; daí seu parentesco com o monstruoso e o grotesco. Com o símbolo, a promessa de salvação; com a alegoria, tudo é desde sempre prematuro e já aniquilado. A forma clássica da epopeia é própria do símbolo; a alegoria tem afinidade com os abismos dionisíacos. Ela é imagem devastadora do nada: a reversão e a transmutação de tudo em tudo.

Aqui nos encontramos com mais um dos temas caros a Artaud: a imagem dos hieróglifos. Eles remetem ao que Benjamin (1984) aponta como apropriação erudita e clássica da escrita egípcia pelo barroco do século XVII. Como escrita sagrada, os hieróglifos estão sujeitos à inteligibilidade profana. Aí se despedaça a sua completude simbólica. O barroco fratura o mundo, fraturando a linguagem, porque desconfia do divino. Com Artaud, o hieróglifo é tentativa de trazer à presença as próprias coisas, quebrando as cadeias narrativas impostas pelo texto dramático. Então, o mais próximo se torna, simultaneamente, o mais distante. O hieróglifo é potência de presença no espaço e temporalidade aiônica.

As palavras têm seu reino invadido pelas imagens. Na cena contemporânea, as violações de fronteiras desfazem a distinção arte/vida, atacando e empurrando para longe a representação. Mas, em seu retorno, eterno e inapelável, ela mostra que o ataque à ordem é correlato da Ordem e das ordens.

A ruína é um componente da linguagem, alegorizando a transitoriedade das coisas e das significações. O cenário barroco é de monumentos despedaçados, da sobrevivência em meio a escombros. As ruínas da Antiguidade são interrogadas pelo moderno, que as exalta para rebaixá-las, como faz Camões. As ruínas contemporâneas remetem a uma trituração do passado e se voltam para a carne, onde não há lugar para a salvação, a não ser pela saúde e o fitness, os implantes, as medicalizações. Mas a ruína também é pompa. Os estilhaços misturam-se, na incansável procura de inteireza. A acumulação e a junção de diferentes mundos - vegetal, animal e mineral - é um princípio compartilhado com o barroco contemporâneo, que leva as misturas aos extremos da hibridização dos corpos. O grotesco e o monstruoso se impõem, em rituais sempre renovados e onde o simbólico (ou o que sobra dele) se faz alegórico. 
Artaud é inflexível no tensionamento da transcendência com a imanência.

O tempo do barroco é a transitoriedade confrontada com o que escapa ao domínio do humano. O tempo atual é de presentes contíguos e acasalados. Mas a exaltação do presente, aliás sempre fugidio, não impede a espessura melancólica dos períodos de decadência que indagam ou desdenham o futuro. Fugacidade e extravagância tentam encobrir as lacunas, apoteoticamente. Se o símbolo atrai o homem para o seu âmbito transcendente e lhe promete a estabilidade das significações e das crenças, a alegoria captura o divino e o faz terreno. Hoje, ela contrapõe o terreno ao terreno, a carne ao corpo, profanando, com a arte, a única religião, segundo Agamben: a do capitalismo. Capturamos imagens para proliferar imagens, desmembrar os circuitos midiáticos, trafegando em superfícies sem espessura; as imagens nada escondem, nada revelam. Elas ganham, no teatro - este dispositivo de fazer ver e ouvir - a consistência da vida dilacerada, presença que se desdobra e redobra em morte e ausência para recobrar memória e tragicidade: são "linhas de enunciação" (Deleuze, 1996) que atravessam os regimes de enunciados e luzes, suportando novas produções subjetivas.

Alice e Baltazar (dramaturgia e direção de Homero Kaneko, Rio, 2018) faz, dos textos projetados, puras imagens em contrastes e superposições de planos. Palavras projetadas e assim transmutadas em imagens, fazendo lembrar que o drama barroco foi feito também para ser lido. É que o espetáculo é a própria palavra. Mas a pompa logo assume sua tristeza; o carnaval é desolador e melancólico, o festejo é da fragmentação. Alice e Baltazar é denúncia barroca da desordem, ao mesmo tempo em que procura instaurá-la como ordem, mostrando-a precária, porém possível. Dispersando e conjugando as significações, a disjunção impede as dicotomias símbolo/ alegoria, ordem/desordem. Os planos e camadas de imagens dobram-se e desdobram-se, conectam e desconectam presentes. As emoções se fazem do choque de fragmentos. O carnaval - o da cena teatral e o da Marquês de Sapucaí - é luto e luxo.

Assim também Para não morrer (dramaturgia de Francisco Mallman baseada em Eduardo Galeano. Curitiba, 2018). Uma Sheherazade ensanguentada e velha como os tempos conta histórias de mulheres reais ou fictícias, para não deixar que elas morram definitivamente e possam viver na memória. Uma memória de retalhos da América Latina oprimida. A contadora de histórias é alegoria de si mesma, uma espécie de figura materna e arquetípica, enraizada na cadeira onde se senta, brotando de uma árvore cujos ramos e raízes são desejos, maus tratos, genocídios, arbitrariedades, alegrias, irreverências, esperanças, astúcias. Nela tudo se mistura; aquelas que são lembradas - e cujos nomes podem ter sido esquecidos - terão garantida sua permanência no mundo, para além de todo sofrimento. É que narrar devolve a vida de quem se foi para a vida de quem aqui está. São todas alegorias deste ato cerimonial que honrava os guerreiros gregos mortos em combate.

Aqui se encontram todos os tempos, o tempo. Todos os presentes, a presença que foge. Os tormentos de Artaud são reveladores: do desejo de dar fim à representação para encontrar as coisas, em sua pura presença; de seu corpo como si-mesmo, num combate com forças de retorno. Despojada de nome ou de imagem, a coisa se fende e cava distância suficiente consigo mesma para restabelecer designações. 
É assim que Dionísio morre e renasce no nascimento e na morte do teatro. A representação se faz e desvanece, do mesmo modo que o dispositivo wagneriano é desmontado por Artaud: daí a cena contemporânea, um movimento que vai de um polo a outro sem nunca deter-se; um trânsito "entre". Assim também podemos ver a articulação posta na crise que vai da tragédia à morte de Sócrates e Cristo e abre o horizonte do drama de martírio, conforme verificamos. São todas situações que mostram não uma alternativa, mas uma paradoxal afirmação de contrários: temporalidade aiônica ou monádica, onde se manifesta uma dificuldade com a descrição de processos cronológicos. Ao que tudo indica, somos pós-dramáticos a preço de sermos também pré-dramáticos, na euforia do eterno retorno. 


\section{Referências}

AGAMBEN, Giorgio. Profanações. São Paulo: Boitempo, 2007.

AGAMBEN, Giorgio. "O que é um dispositivo?". In: O que é o contemporâneo? Chapecó: Editora Argos, 2012.

ARTAUD, Antonin. O teatro e seu duplo. São Paulo: Max Limonad, 1985.

ARTAUD, Antonin. Van Gogh, o suicidado da sociedade. Lisboa: Hiena, 1987.

BAKHTIN, Mikhail. Estética da criação verbal. São Paulo: Martins Fontes, 1997.

BENJAMIN, Walter. Origem do drama barroco alemão. São Paulo: Brasiliense, 1984.

BENJAMIN, Walter. A obra de arte na era de sua reprodutibilidade técnica. In: BENJAMIN, Walter. Sobre arte, técnica, linguagem e política. Lisboa: Relógio d'Água, 1992.

CRARY, Jonathan. 24/7 - Capitalismo tardio e os fins do sono. São Paulo: Cosac Naify, 2014.

CARVALHO, Alessandra Lima de. Dispositivos de intensificação do acontecimento cênico: a obra de arte como abertura para o Dasein autêntico. Rio de Janeiro: Programa de Pós-Graduação em Artes de Cena/Universidade Federal do Rio de Janeiro, 2018. Dissertação de Mestrado.

DEBORD, Guy. A sociedade do espetáculo. Rio de Janeiro: Ed. Contraponto, 1997.

DELEUZE, Gilles. Crítica e clínica. São Paulo: Editora 34, 1997.

DELEUZE, Gilles. Lógica do sentido. São Paulo: Perspectiva, 1994.

DELEUZE, Gilles. Conversações. Rio de Janeiro: Editora 34, 1992.

DELEUZE, Gilles. "O que é um dispositivo?". In: O mistério de Ariana. Lisboa: Vega, 1996.

DELEUZE, Gilles \& GUATARI, Félix. Mil platôs. São Paulo: Ed. 34, 1996, v. 3.

DELEUZE, Gilles \& GUATTARI, Félix. Mil platôs. São Paulo: Ed. 34, 2012, v. 5.

DERRIDA, Jacques. A escritura e a diferença. São Paulo: Perspectiva, 1995.

DETIENNE, Marcel. Dioniso a céu aberto. Rio: Jorge Zahar, 1988. 
FARIAS, Danielle Martins de. Transversalidades e poéticas da cena - articulações entre literatura e teatro e seus procedimentos. Rio de Janeiro: Programa de Pós-Graduação em Artes Cena (PPGAC). Escola de Comunicação, UFRJ, 2019, Dissertação de Mestrado.

FOUCAULT, Michel. As palavras e as coisas. São Paulo: Martins Fontes, 1992.

GADELHA, Carmem. Corpo, espaço, tempo - indagações sobre poética do teatro. Rio: Editora Aretê, 2013.

GADELHA, Carmem. Cena teatral contemporânea: o coro, o nômade, a potência trágica. Revista Sala Preta. São Paulo: 2018. Vol. 18, no 2. Disponível em: https://doi. org/10.11606/issn.2238-3867.v18i2p131-142

HARDT, Michael \& NEGRI, Antonio. Império. Rio: Record, 2001.

HARDT, Michael \& NEGRI, Antonio. Multidão. Rio: Record, 2005.

NIETZSCHE, Friedrich. Origem da tragédia. Lisboa: Guimarães, 1982.

NIETZSCHE, Friedrich. Para a genealogia da moral. Lisboa, Relógio d'Água Editores, 2000.

NIETZSCHE, Friedrich. O caso Wagner: um problema para músicos / Nietzsche contra Wagner: dossiê de um psicólogo. São Paulo: Companhia das Letras, 1999.

SZANIECKI, Barbara. Estética da multidão. Rio: Civilização Brasileira, 2007.

Recebido em: 06/05/2019 Aprovado em: 24/06/2019 